DOI: $10.1515 /$ pts-2017-0037

\title{
MODELLING THE SPATIAL DISTRIBUTION OF WIND ENERGY RESOURCES IN LATVIA
}

\author{
S. Aniskevich ${ }^{1}$, V. Bezrukovs ${ }^{2,3}$, U. Zandovskis ${ }^{1}$, D. Bezrukovs ${ }^{4}$ \\ ${ }^{1}$ Latvian Environment, Geology and Meteorology Centre, \\ 165 Maskavas Str., Riga, LV-1019, LATVIA \\ e-mail: svetlana.aniskevica@lvgmc.lv, \\ ${ }^{2}$ Institute of Physical Energetics, \\ 11 Krivu Str., Riga, LV-1006, LATVIA \\ ${ }^{3}$ Ventspils University College, \\ 101 Inzenieru Str., Ventspils, LV-3601, LATVIA \\ e-mail: elmag@inbox.lv, \\ ${ }^{4}$ Riga Technical University \\ Arzenes Srt., 12/1, Riga, LV-1048, LATVIA
}

The paper studies spatial wind energy flow distribution in Latvia based on wind speed measurements carried out at an altitude of $10 \mathrm{~m}$ over a period of two years, from 2015 to 2016 . The measurements, with $1 \mathrm{~min}$ increments, were carried out using certified measuring instruments installed at 22 observation stations of the Latvian National Hydrometeorological and Climatological Service of the Latvian Environment, Geology and Meteorology Centre (LEGMC). The models of the spatial distribution of averaged wind speed and wind energy density were developed using the method of spatial interpolation based on the historical measurement results and presented in the form of colour contour maps with a $1 \times 1 \mathrm{~km}$ resolution. The paper also provides the results of wind speed spatial distribution modelling using a climatological reanalysis ERA5 at the altitudes of $10,54,100$ and $136 \mathrm{~m}$ with a $31 \times 31 \mathrm{~km}$ resolution. The analysis includes the comparison of actual wind speed measurement results with the outcomes of ERA5 modelling for meteorological observation stations in Ainazi, Daugavpils, Priekuli, Saldus and Ventspils.

Keywords: wind speed, wind energy, measurements, modelling, ERA5.

\section{INTRODUCTION}

The territory of Latvia does not possess any significant reserves of fossil fuels. Therefore, the needs of the national economy are mainly met through the import of electricity and energy carriers. This creates the dependency of the country's economy on external supplies. Hence, the state is interested in the development of power plants using available national energy resources [1]. 
The availability of financial support from the European Development Funds stimulates the construction of power generating stations [2]. This fact also encourages investors to consider the commercial use of alternative renewable energy sources, which are available for use on the industrial scale.

Favourable geographical location of the country on the shore of the Baltic Sea makes its territory open from the western direction for southwestern winds, which are prevailing in this region. The western part of Latvia is dominated by forestcovered plains, while in the eastern part of the country there are hilly areas of up to $300 m$ high.

Wind flows from the sea possess a significant wind energy potential, which can be used to produce electricity. Wind speed measurement results performed with $1 \mathrm{~min}$ increments allow us to calculate the density of wind energy that a wind current in a given region can carry. Based on the information, an estimate of the average annual power production for the projected Wind Power Plants (WPP) can be made [3], [4].

When choosing a construction site for a WPP, it is necessary to take into account the natural specificities of the landscape and estimate the density of wind energy in the given area. In this regard, information on the spatial distribution of the resource of wind energy on the entire territory of the country is of utmost importance for the national economy [5].

The rest of the paper is structured as follows: Section 2 provides the description of meteorological stations in Latvia and measuring equipment. Section 3 presents the model of spatial distribution of wind speed measurements obtained at the altitude of $10 \mathrm{~m}$. Section 4 introduces the model of spatial distribution of wind energy resources in Latvia. Section 5 presents summarised results, discusses their implications and makes conclusions.

\section{THE NETWORK OF METEOROLOGICAL STATIONS AND MEASUREMENT RESULTS}

In Latvia, for more than 100 years, there has been a network of meteorological observation stations that perform the collection and archiving of high quality representative meteorological data. For the measurements at the stations, only calibrated sensors and certified equipment, according to international requirements, are used. The monitoring of climate and weather conditions is carried out at 22 stations, shown in Fig. 1. A majority of the stations are currently operating in an automated mode.

The stations continuously measure and record the speed and direction of wind, measure atmospheric pressure, humidity and air temperature, as well as other meteorological parameters. In order to measure wind speed over the considered time period, 10 stations were equipped with Vaisala WAA 151 anemometers, while 8 stations had Vaisala WMT 702 ultrasonic wind sensors and at 4 stations anemometers were replaced by ultrasonic sensors.

In order to calculate the average wind speed with $1 \mathrm{~min}$ increments, an anemometer measures the actual wind speed every $2 s$, while the ultrasonic sensor every $3 \mathrm{~s}$. All wind speed sensors are installed at a height of $10 \mathrm{~m}$, except for Riga $(36 \mathrm{~m})$, Kolka $(20 \mathrm{~m})$ and Pavilosta (since December 2015 - $18 \mathrm{~m}$ ) meteorological 
observation stations. Prior to the analysis, outliers were removed from the dataset.

There are a number of publications devoted to the issue of estimating the magnitude of wind energy resource potential and its distribution on the territory of Latvia [6]-[9]. However, the reliability of these studies is not high, as they are based on the analysis of accessible public wind speed data, which is designed to study climate change. The correct estimates can be done only based on the analysis of the results of wind speed measurements performed simultaneously and at the same height above the ground in different regions of the country for a period of at least one year.

This article is based on data obtained using certified measuring sensors installed at meteorological observation stations belonging to the LEGMC $^{1}$. The results of physical measurements are recorded as discrete values of wind speed with $1 \mathrm{~min}$ increments from 22 observation stations at $10 \mathrm{~m}$ height above the ground, over a period from $01 / 01 / 2015$ to $31 / 12 / 2016$.

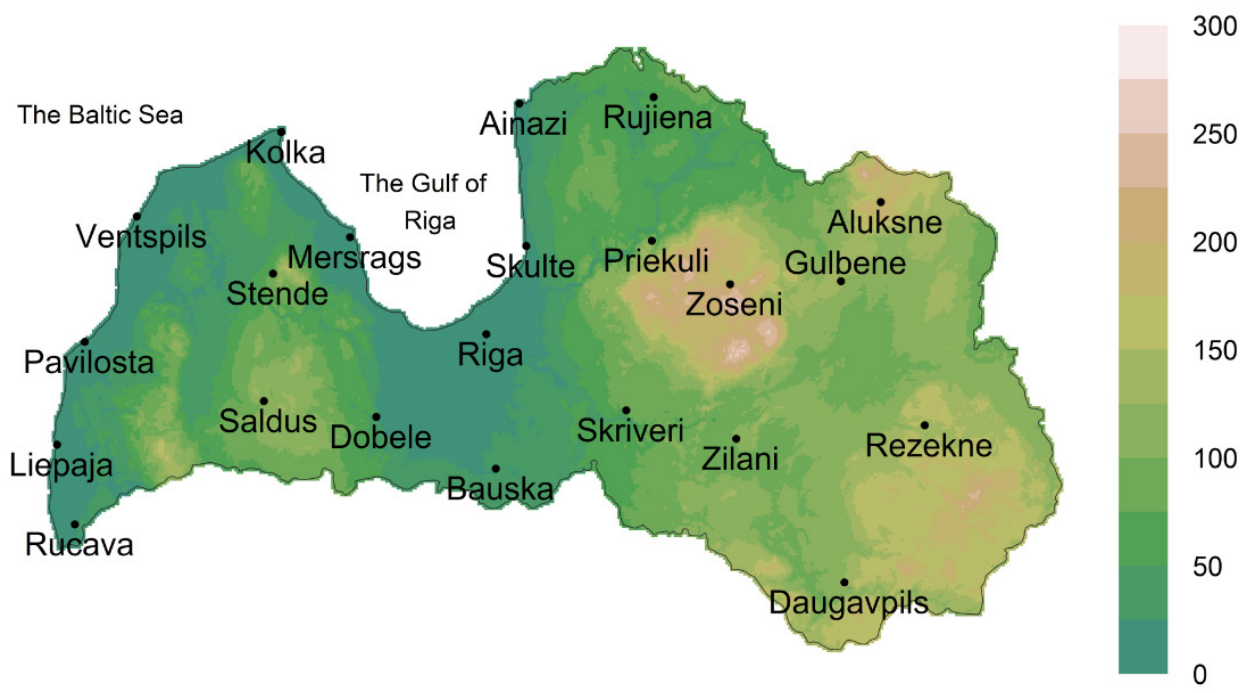

Fig. 1. Map of Latvia with the locations of 22 meteorological stations and the mean elevation above sea level $(\mathrm{m})$ with a $1 \times 1 \mathrm{~km}$ resolution.

The presentation of the results of physical measurements in the form of a model of the spatial distribution of wind speed allows us to consider, as an alternative, other methods related to wind speed prediction. For instance, the article also presents the models of the spatial distribution of wind speed at the heights of 10, 54, 100 and $136 \mathrm{~m}$, developed by using climatological reanalysis datasets ERA5 from 2015 to 2016 for the Latvian territory [10].

\section{THE MODEL OF WIND SPEED SPATIAL DISTRIBUTION}

The uniform distribution of observation stations on the territory of the country and a long measurement period allow us to present the results as a visual model in Fig. 2. The colour palette used in the model allows allocating areas in the territory

\footnotetext{
${ }^{1}$ https://www.meteo.lv/meteorologijas-operativa-informacija
} 
of Latvia with the same level of wind speed. In this case, the spatial distribution of the average value of the wind speed $V_{a v g}$ is depicted in steps of $0.5 \mathrm{~m} / \mathrm{s}$. The value of the average wind speed for the measurement period at the measurement points was calculated as follows:

$$
V_{\text {avg }}=\frac{1}{n} \sum_{i=1}^{n} V_{i}
$$

where $V_{i}-$ the average wind speed with $1 \mathrm{~min}$ increments, $\mathrm{m} / \mathrm{s}$;

$n$ - the number of measurements for the observation period from $01 / 01 / 2015$ to $31 / 12 / 2016$;

$i$-observation $1,2,3, \ldots, n$.

In order to estimate the value of the meteorological parameter between the observation stations, a spatial interpolation of measured data was used. In this article, a geostatistical method - universal kriging - was applied [11].

Apart from the observed values from the nearest stations, this method also uses additional spatial factors that influence meteorological parameters. The most relevant factors for average wind speed interpolation are geographical coordinates in the metric system LKS-92, elevation above the sea level and distance from the Baltic Sea or the Gulf of Riga. Spatial interpolation is performed on a grid with a resolution of $1 \mathrm{x} 1 \mathrm{~km}$.
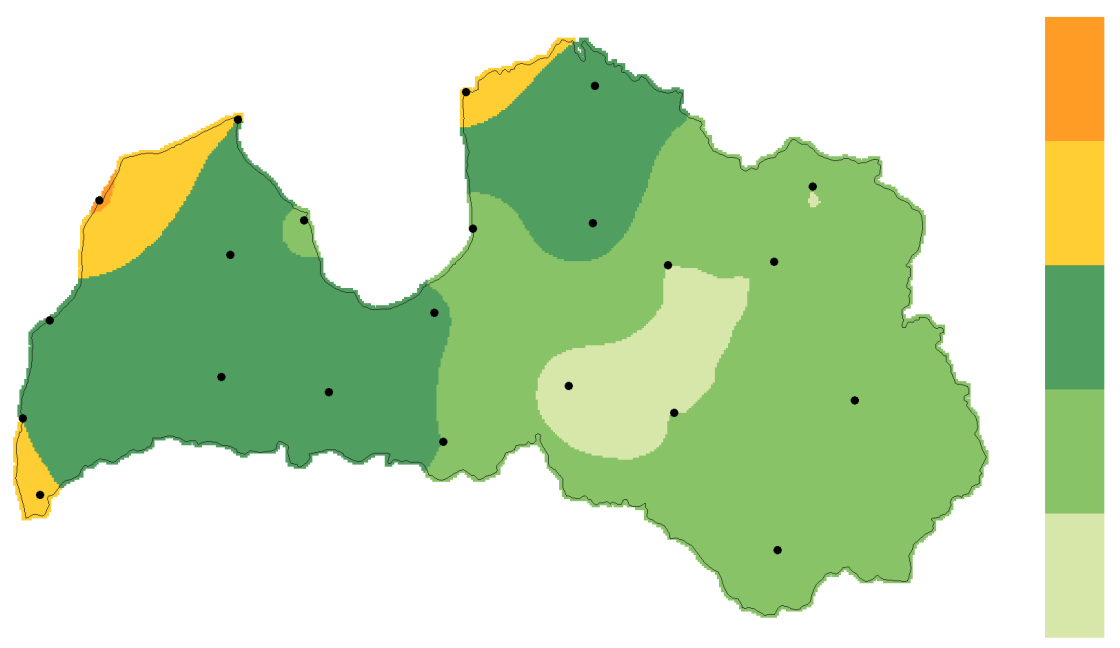

Fig. 2. Model of the spatial distribution of average values of wind speed $\mathrm{m} / \mathrm{s}$ at an altitude of $10 \mathrm{~m}$ above the ground on the territory of Latvia.

Modern weather modelling technologies allow predicting the magnitude of wind speed above the surface of land and sea. For example, climatological reanalysis dataset ERA5, created by the European Centre for Medium-Range Weather Forecasts (ECMWF), provides information for a variety of meteorological parameters. ERA5 covers the Earth with a $31 \mathrm{~km}$ grid and stratifies the atmosphere into 137 
levels from the surface up to the height of $80 \mathrm{~km}$. The first 7-year segment of the ERA5 dataset is now available for public use [12]. The information available to users allows obtaining the average wind speed with $2 \mathrm{~h}$ increments for any point on the surface of the Earth. Figs. 3 and 4 present the models of spatial distribution of wind speeds in the territory of Latvia for the heights of 10, $54 \mathrm{~m}$ and 100, $136 \mathrm{~m}$, respectively, which are estimated using the ERA5 dataset over a time period from $01 / 01 / 2015$ to $31 / 12 / 2016$.
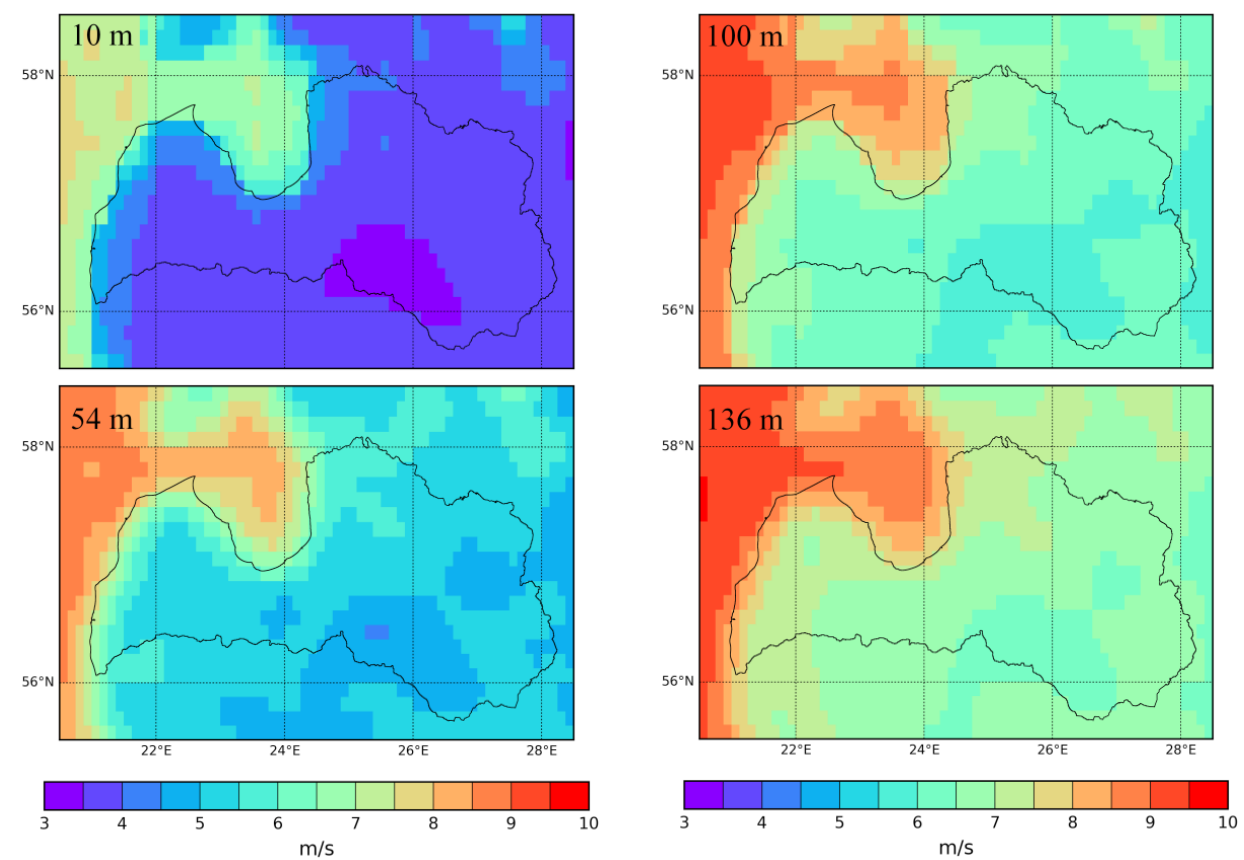

Fig. 3. Models of spatial distribution of average wind speed at the heights for $10 \mathrm{~m}$ and $54 \mathrm{~m}$, estimated using ERA5.

Fig. 4. Models of spatial distribution of average wind speed at the heights for $100 \mathrm{~m}$ and $136 \mathrm{~m}$, estimated using ERA5.

The use of these models does not guarantee high accuracy and resolution, in contrast to physical measurements obtained at the observation stations, but it shows how the boundaries of the wind speed distribution regions change with an increasing altitude. The models also allow identifying the presence of areas that have relatively low and high potentials for wind energy. Specifically, wind speed on the coast of the Baltic Sea in the western part of the country is much higher than in the east, while the lowest values of wind speed are recorded in the central part of the country.

The results of wind speed measurements at meteorological observation stations in the area of Ainazi, Daugavpils, Priekuli, Saldus and Ventspils and ERA5 simulations are given in Table. Comparative analysis of these data shows that the results of ERA5 simulation consistently exceed the measured historical values in all regions by $\sim(20-50) \%$. It is likely that ERA5 modelling results are strongly influenced by the structure of the terrain. However, modelling results presented in the form of contour maps can serve as a basis for estimating and comparing the intensity of wind speed in the central part of the country and on the shores of the Baltic Sea. That makes them useful at the planning stage - in the process of selecting the most 
suitable sites for WPP construction and predicting the distribution of wind energy potential on the territory of Latvia.

In order to estimate the reliability of ERA5 simulation, the values of wind speed at the heights of 54, 100 and $136 \mathrm{~m}$ can be crosschecked with the results of physical measurements at the heights of up to $200 \mathrm{~m}$ above the ground in the time period from 01/03/2014 to 01/03/2015 obtained using laser measuring complex Pentalum SpiDAR [13]. Historical wind speed measurements used for the comparison were carried out in the coastal zone of Latvia - in Ventspils region. The performed comparison shows that the deviation of the results of physical wind speed measurements at the altitudes of 54, 100 and $136 \mathrm{~m}$ from the estimates of the average wind speed values obtained using ERA5 technology does not exceed $20 \%$. As the altitude above the ground level increases, the turbulence of airflows decreases; therefore, the use of simulation technology gives higher accuracy in determining wind speed.

An important observation with respect to the models of spatial distribution of wind speed at the heights of 54,100 and $136 \mathrm{~m}$ is the continuous evolution of the boundary pattern, which determines the transition of the velocity levels. This indicates the preservation of the regularity of the change in the magnitude of the wind speed with increasing altitude.

\section{MODEL OF THE SPATIAL DISTRIBUTION OF WIND ENERGY}

The value of the energy unit density that a uniform airflow carries over an area of $1 \mathrm{~m}^{2}$ is represented as follows:

$$
P=\frac{1}{2} \rho V^{3}
$$

where $\rho$ - is air density $\left(1.23 \mathrm{~kg} / \mathrm{m}^{3}\right.$ for a standard condition at the sea level and temperature $15^{\circ} \mathrm{C}$ );

$V-$ is wind speed, $m / s[14]$.

As follows from Eq. 2, the magnitude of the airflow energy is in a cubic relationship with its speed $V$. Therefore, in order to estimate wind energy, the magnitude of which is constantly changing, it is not correct to use the average wind speed calculated by Eq. 1. However, it should be noted that, in practice, wind speed values recorded in the database are discrete values, representing averaged results of measurements made over a certain time interval. When working with a large amount of data obtained over a long period of observations it is practical to split wind speed measurement results into bins that correspond to the speed intervals of a certain size. For each bin, the total recurrence time, expressed as a percentage of the total measurement time, is determined. The resulting frequency distribution function for the average wind speed characterises the qualitative side of the wind data and is used to estimate the energy carried by the flow with an uneven speed.

The curves depicted in Fig. 5 are functions of the empirical frequency distribution of bin values corresponding to the discrete measures of the average wind 
speed $V_{a v g}$ with an interval of $1 \mathrm{~m} / \mathrm{s}$. The results of the measurements were obtained at meteorological observation stations in Ainazi, Daugavpils, Priekuli, Saldus and Ventspils during the measurement period from $01 / 01 / 2015$ to $31 / 12 / 2016$.

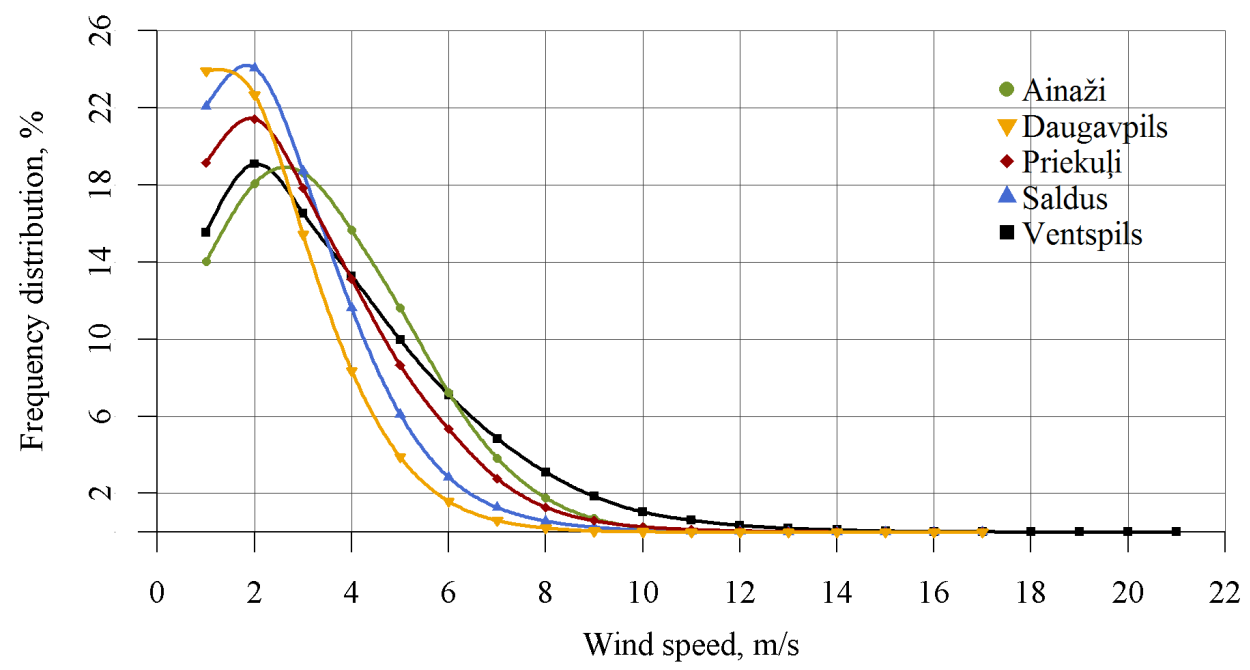

Fig. 5. Frequency distribution functions of average wind speed values $V_{a v g} \mathrm{~m} / \mathrm{s}$ over the period of observations from $01 / 01 / 2015$ to $31 / 12 / 2016$ for 5 meteorological observation stations in Latvia at an altitude of $10 \mathrm{~m}$ above the ground.

It is important to note that the cubic relationship between the wind energy and its speed results in a situation that wind speed profile that is characterised with bigger displacement to the right typically has higher energy resource potential. In the case of Latvia, distribution functions most displaced to the right frequency correspond to the measurements obtained at Ventspils and Ainaži stations.

Against this background, the density of wind energy for the period of observations can be obtained either by means of summing separate energy quants corresponding to each wind speed bin, or through the use of average cubic speed $V_{\text {avg cub }}$ in the calculations. In the latter case, the value of average energy density can be expressed as follows:

$$
P_{\text {avg }}=\frac{1}{2} \rho V_{\text {avg.cub }}^{3}
$$

where

$$
V_{\text {avg.cub }}=\sqrt[3]{\frac{1}{n} \sum_{i=1}^{n} V_{i}^{3}},
$$

where $V_{i}-$ is the average wind speed with $1 \mathrm{~min}$ increments, $\mathrm{m} / \mathrm{s}$;

$n$ - the number of observations of average wind speed for the period of observations;

$i$ - the observation number $1,2,3, \ldots, n$. 
The model of the spatial distribution of average cubic wind speed with the resolution of $1 \times 1 \mathrm{~km}$ obtained as a result of the interpolation of calculated values is presented in the form of a contour map in Fig. 6.
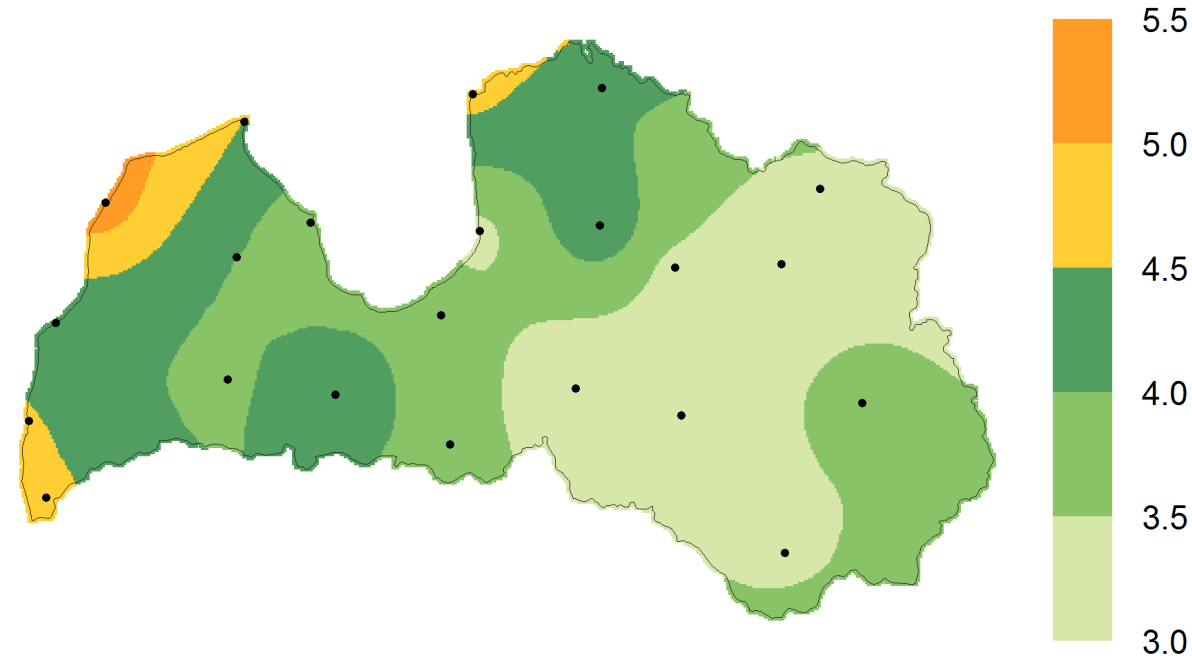

Fig. 6. Model of the spatial distribution of average cubic wind speed $\mathrm{m} / \mathrm{s}$ at an altitude of $10 \mathrm{~m}$ above the ground in Latvia.

The amount of energy carried by airflow is proportional to the value of the average cubic wind speed (4); therefore, the map in Fig. 6 is equivalent to the density of the wind energy flux, expressed in $\mathrm{W} / \mathrm{m}^{2}$. Moreover, the division of the territory of Latvia into five regions according to the average cubic wind speed can serve as a tool for the comparative evaluation of the resource of wind energy that these regions have.

If the maximum value of average energy density, which wind carries on the shore of the Baltic Sea, is assumed to be 1.0, then the values of the average energy density in relative units for each observation station shown in Fig. 1 will be determined from the following ratio:

$$
P^{\prime}{ }_{\text {avg.i }}=V_{\text {avg.cub.i }}^{3} / V_{\text {avg.cub.max }}^{3},
$$

where $V_{\text {avg.cub.max }}-$ the maximum observed value of the average cubic speed at the station in Ventspils region, $\mathrm{m} / \mathrm{s}$;

$V_{\text {avg.cub.i }}$ - the value of average cubic wind speed at each of the 22 observation stations, $\mathrm{m} / \mathrm{s}$;

$i$ - station $1,2,3, \ldots, 22$.

As a result of interpolation of the obtained values, a model of the spatial distribution of the mean wind energy density in relative units with a resolution of $1 \mathrm{x} 1 \mathrm{~km}$ for the territory of Latvia has been compiled. The results of the model are presented in the form of a contour map in Fig 7. 


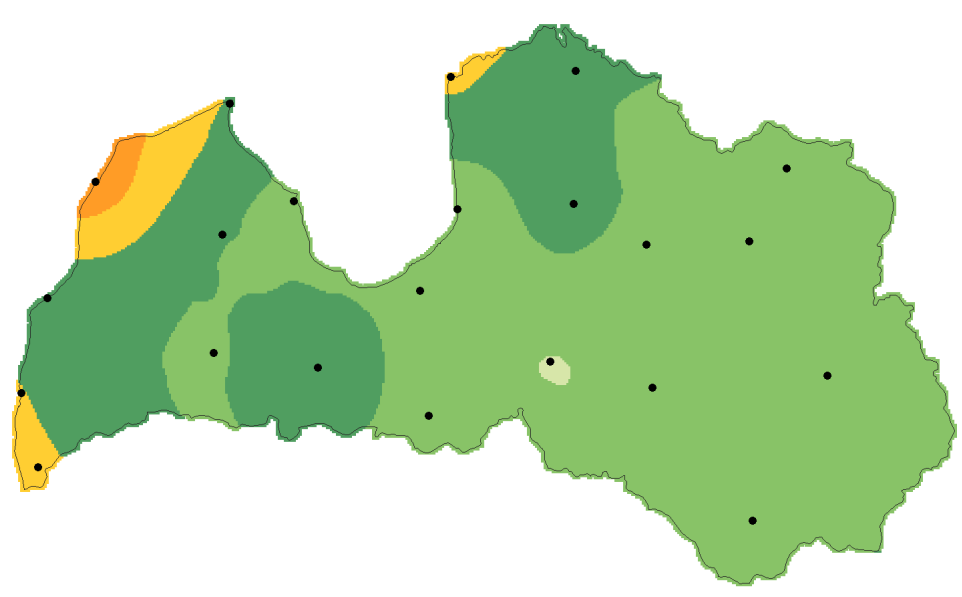

Fig. 7. Model of the spatial distribution of the average wind energy density in relative units at an altitude of $10 \mathrm{~m}$ above the ground in the territory of Latvia.

Some differences in the distribution of the boundaries of the regions in Figs. 6 and 7 can be attributed to the difference in the scale of the values of the models represented in the figures, corresponding to the and the density of wind energy. For more precise comparison of wind energy intensity in the selected regions of Latvia, Table gives the numerical values of the energy density determined on the basis of the measurements made at meteorological stations.

The visual representation of the distribution of the resource of wind energy on the map makes it possible to predict the efficiency of wind generators with a mast height of $10 \mathrm{~m}$ on the entire territory of Latvia. Importantly, the map in Fig. 7 shows that in the most of the eastern part of the country the efficiency of wind generators will be three to four times lower than in the western part of the country adjacent to the Baltic Sea.

Table 1

Average Wind Speed $V_{a v g}, V_{a v g . c u b .} m / s$ and Wind Energy Density in

Relative Units $P^{\prime}{ }_{a v g}$ Obtained as a Result of Physical Measurements at Selected

Meteorological Observation Stations and Based on Estimations Using ERA5 Dataset

\begin{tabular}{|c|c|c|c|c|c|c|c|}
\hline & \multicolumn{3}{|c|}{ Results of measurements } & \multicolumn{4}{|c|}{ Results of ERA5 modelling } \\
\hline Station & 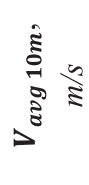 & 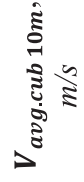 & $\begin{array}{c}\tilde{E} \\
\text { है } \\
\text { है } \\
\text { है }\end{array}$ & 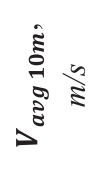 & 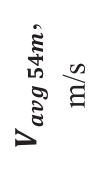 & 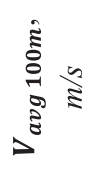 & 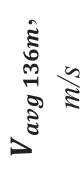 \\
\hline Ventspils & 4.1 & 5.4 & 1.00 & 6 & 7.4 & 8.1 & 8.5 \\
\hline Ainazi & 3.8 & 4.7 & 0.66 & 4.7 & 6.7 & 7.2 & 7.9 \\
\hline Priekuli & 3.4 & 4.5 & 0.58 & 3.9 & 5.5 & 6.5 & 7.1 \\
\hline Saldus & 3.0 & 3.9 & 0.38 & 3.8 & 5.3 & 6.4 & 6.9 \\
\hline Daugavpils & 2.5 & 3.3 & 0.23 & 3.6 & 4.9 & 5.9 & 6.4 \\
\hline
\end{tabular}




\section{CONCLUSIONS}

The study developed the models of the spatial distribution of wind speed and wind energy density on the territory of Latvia. The models were created on the basis of generalisation of the results of physical measurements of wind speed at an altitude of $10 \mathrm{~m}$ above the ground.

The models were constructed using the method of spatial interpolation on the basis of measured values and presented in the form of colour contour maps with a 1x1 km resolution. Physics measurements were carried out at 22 meteorological observation stations belonging to the LEGMC for a time period from $01 / 01 / 2015$ to $31 / 12 / 2016$.

The paper presented the results of an alternative modelling approach towards obtaining the spatial distribution of wind speed using the ERA5 weather modelling technology at the altitudes of 10,54, 100 and $136 \mathrm{~m}$ with a $31 \times 31 \mathrm{~km}$ resolution.

The paper provided the comparative analysis of the results of physical measurements and modelling of average wind speed for meteorological observation stations in Ainazi, Daugavpils, Priekuli, Saldus and Ventspils.

The visual representation of the distribution of wind energy resource presented in the paper makes it possible to estimate the efficiency of wind generators on the whole territory of Latvia.

The developed models of the spatial distribution of wind speed and wind energy can serve as a practical tool and reference material for analysing the prospects of using wind generators in various regions of Latvia and assessing the possibility of commercial use of wind energy at a height of $10 \mathrm{~m}$.

\section{ACKNOWLEDGEMENTS}

The research has been carried out within the project "New European Wind Atlas" (NEWA), ENER/FP7/618122/NEWA ERA-NET PLUS, supported by the European Commission under the 7th Framework Programme for Research, Technological Development and Demonstration.

\section{REFERENCES}

1. Shipkovs, P., Kashkarova, G., Lebedeva, K., \& Migla, L. (2012). Use of renewable energy resources for reduction of environmental pollutions. In the Fourth IASTED African Conference on Power and Energy Systems (AfricaPES 2012), 3-5 September 2012 (pp. 79-85). Gaborone, Botswana. CD Proceedings.

2. Bobinaite, V., \& Priedite, I. (2015). RES-E support policies in the Baltic States: electricity price aspect (part II). Latvian Journal of Physics and Technical Sciences, 2, 13-25.

3. Bezrukovs, V.P., Bezrukovs, V.V., \& Zacepins, A.J. (2014). Comparative efficiency of wind turbines with different heights of rotor hubs: Performance evaluation for Latvia. $J$. Phys.: Conf. Ser. 524 012113. doi:10.1088/1742-6596/524/1/012113

4. Godoy, S., M., \& Farret, F.A. (2015). Modelling and Analysis with Induction Generators (3rd Edition). CRC Press. 
5. Turcik, M., Obuševs, A., Oḷeiņikova, I., \& Junghans, G. (2013). Assessment of wind production impacts to a power system and market formation in Baltic. Power and Electrical Engineering, 31, 31-37.

6. Vēja karte un kvalitāte. (n.d.) Available at http://www.kerveju.lv/veja_karte.php

7. Ostapenko, J., \& Gamalejevs, A. (2004). Latvian Wind Energy Guide. Riga.

8. Atjaunojamā enerğija Latvijā. Project No. 2/EEZLV02/ 14/GS/044 Contract No. 2/ EEZLV02/14/GS/044/011 24.04.2015/ Available at http://kpfi.liepu.lv/wpcontent/uploads/2016/03/Renewable_energy_LV.pdf

9. Bezrukovs, V., Zacepins, A., Bezrukovs, V., \& Komashilovs, V. (2016). Investigations of wind shear distribution on the Baltic shore of Latvia. Latvian Journal of Physics and Technical Sciences, 53(3), 3-10.

10. ERA5 Public Release 2010-2016. Available at https://climate.copernicus.eu/era5-publicrelease-2010-2016

11. Bivand, R. S., Pebesma, E. J., \& Gómez-Rubio, V. (2008). Applied Spatial Data Analysis with $R$ (2nd edition). New York: Springer.

12. Hennermann, K., \& Berrisford, P. (2017). ERA5 data documentation. Available at https:// software.ecmwf.int/wiki/display/CKB/ERA5+data+documentation

13. Bezrukovs, V., Zacepins, A., Bezrukovs, Vl., \& Komashilovs, V. (2016). Comparison of methods for evaluation of wind turbine power production by the results of wind shear measurements on the Baltic shore of Latvia. Renewable Energy, 96, Part A, 765-774.

14. Manwell, J. F., McGowan, J. G., \& Rogers, A. L. (2009). Wind Energy Explained: Theory, Design and Application. John Wiley \& Sons Ltd.

\title{
VĒJA ENERG̣IJAS RESURSU TELPISKĀ SADALİJUMA MODELĒŠANA LATVIJAS TERITORIJĀ
}

\author{
S. Aṇiskeviča, V. Bezrukovs, U. Zandovskis, D. Bezrukovs
}

Kopsavilkums

Publikācijā tiek pētīts vēja enerǵijas plūsmas telpiskais sadalījums Latvijas teritorijā, kas balstîts uz vēja ātruma novērojumiem $10 \mathrm{~m}$ augstumā divu gadu periodā - no 2015. līdz 2016. gadam. Ik minūšu novērojumi veikti, izmantojot sertificētas mēriekārtas 22 meteoroloǵiskajās novērojumu stacijās, kas pieder Latvijas Vides, geologijas un meteorologijas centram - Latvijas Nacionālajam hidrometeorolog̣iskajam un klimatologískajam dienestam. Vidējā vēja ātruma un enerǵijas blīvuma telpiskā sadalījuma modelis tika iegūts ar telpiskās interpolācijas metodi, kas balstîta uz novērotajām vērtībām, un attēlots krāsu kontūru karšu veidā ar izšķirtspēju 1 x $1 \mathrm{~km}$. Publikācijā tiek sniegti arī vēja ātruma telpiskā sadalījuma modelēšanas rezultāti no klimatiskās reanalīzes ERA5 10, 54, 100 un $136 \mathrm{~m}$ augstumā ar 31x31 km izšḳirtspēju. Analīzē ir iekḷauts faktisko vēja ātrumu mērījumu salīdzinājums ar ERA5 modelēšanas rezultātiem meteorolog̣isko novērojumu stacijās Ainažos, Daugavpilī, Priekuḷos, Saldū un Ventspilī.

05.11.2017. 